\title{
Foreword to the special issue: decadal scale drought in arid regions
}

\author{
Zong-Liang Yang ${ }^{1,2} \cdot$ Zhuguo Ma $^{1}$
}

Received: 27 July 2017 / Accepted: 3 August 2017 / Published online: 15 August 2017

(C) Springer Science+Business Media B.V. 2017

Under the support of the National Basic Research Program from The Ministry of Science and Technology (MOST) of the People's Republic of China, a project entitled "Mechanisms and Influences of Decadal Climate Change in Global Arid and Semi-arid Regions" was conducted during the period of 2012-2016. This special issue assembles the papers that were directly funded by the grant or solicited to represent a broad range of topics, which are briefly reviewed below.

The papers can be grouped into four main research themes. The first group depicts the spatiotemporal characteristics of precipitation based on instrumental data (Pei et al. 2017; Yang et al. 2017) and proxy data (Zhang et al. 2017). These papers then connect the precipitation variability to various controlling factors, including the Pacific Decadal Oscillation.

Based on field observations, reanalysis, and numerical modeling, the second group studies the role of land-atmosphere interaction in modulating runoff variability and their trends over arid and semi-arid regions in China (Li et al. 2017b; Zheng et al. 2017). These studies have revealed distinct regional patterns and trends, suggesting complex relationships between runoff variability and terrain, soils, vegetation, and climate.

Land use and land cover changes are known to cause regional changes in hydrology and climate. Focusing on arid and semi-arid regions in China, the papers in the third group study the climatic impact of vegetation degradation (Chen et al. 2017) and reforestation (Wang and Cheung 2017). Xu and Yang (2017) further assess relative contributions of increased greenhouse gases and land use and land cover change to climate change. Li et al. (2017a) quantify natural versus anthropogenic climate change.

The fourth group addresses the uncertainties in estimating historical drought changes in arid and semi-arid regions (Dai and Zhao 2017) and documents the uncertainties in the modeled

This foreword is part of a "Special Issue on Decadal Scale Drought in Arid Regions" edited by Zong-Liang Yang and Zhuguo Ma

Zong-Liang Yang

liang@jsg.utexas.edu

1 Key Laboratory of Regional Climate-Environment Research for Temperate East Asia, Institute of Atmospheric Physics, Chinese Academy of Sciences, Beijing, China

2 Center for Integrated Earth System Science, University of Texas at Austin, Austin, TX 78712, USA 
historical and future drought changes (Zhao and Dai 2017). These results provide a solid background for assessing the vulnerability of and risk to water resources over arid and semi-arid areas under the combined effects of decadal drought and human activities (Xia et al. 2017).

These research findings have helped advance our systematic understanding of the mechanisms and influences of decadal drought in global arid and semi-arid regions from perspectives of natural processes and human activities. They also have provided theories and methods for projecting future decadal scale droughts as well as services for regional and social sustainability.

Acknowledgements We would like to thank all the contributors to this special issue. This paper was supported by grants from the National Basic Research Program of China (2012CB956201) and the National Natural Science Foundation of China (41275085 and 41375088).

\section{References}

Chen L, Ma ZG, Zhao TB (2017) Modeling and analysis of the potential impacts on regional climate due to vegetation degradation over arid and semi-arid regions of China. Clim Chang no DOI numbers

Dai AG, Zhao TB (2017) Uncertainties in historical changes and future projections of drought. Part I: estimates of historical drought changes. Clim Chang. doi:10.1007/s10584-016-1705-2

Li CX, Zhao TB, Ying KR (2017a) Quantifying the contributions of anthropogenic and natural forcings to climate changes over land during 1946-2005. Clim Chang no DOI numbers

Li MX, Ma ZG, Lv MX (2017b) Variability of modeled runoff over China and its links to climate change. Clim Chang. doi:10.1007/s10584-015-1593-X

Pei L, Xia JJ, Yan ZW, Yang H (2017) Assessment of the Pacific decadal oscillation's contribution to the occurrence of local torrential rainfall in north China. Clim Chang. doi:10.1007/s10584-016-1610-8

Wang L, Cheung KKW (2017) Potential impact of reforestation programmes and uncertainties in land cover effects over the loess plateau: a regional climate modeling study. Clim Chang. doi:10.1007/s10584-016-1848-1

Xia J, Ning LK, Wang Q, Chen JX, Wan L, Hong S (2017) Vulnerability of and risk to water resources in arid and semiarid regions of West China under a scenario of climate change. Clim Chang. doi:10.1007/s10584-016-1709-y

$\mathrm{Xu}$ ZF, Yang ZL (2017) Relative impacts of increased greenhouse gas concentrations and land cover change on the surface climate in arid and semi-arid regions of China. Clim Chang no DOI numbers

Yang Q, Ma ZG, Xu BL (2017) Modulation of monthly precipitation patterns over East China by the Pacific Decadal Oscillation. Clim Chang. doi:10.1007/s10584-016-1662-9

Zhang Y, Tian QH, Guillet S, Stoffel M (2017) 500-yr. precipitation variability in Southern Taihang Mountains, China, and its linkages to ENSO and PDO. Clim Chang. doi:10.1007/s10584-016-1695-0

Zhao TB, Dai AG (2017) Uncertainties in historical changes and future projections of drought. Part II: modelsimulated historical and future drought changes. Clim Chang. doi:10.1007/s10584-016-1742-X

Zheng ZY, Ma ZG, Li MX, Xia JJ (2017) Regional water budgets and hydroclimatic trend variations in Xinjiang from 1951 to 2000. Clim Chang. doi:10.1007/s10584-016-1842-7 